\title{
МЕДИКАМЕНТОЗНА ПРОФІЛАКТИКА ХРОНІЧНОЇ СЕРЦЕВОЇ НЕДОСТАТНОСТІ ПІСЛЯ ІНФАРКТУ МІОКАРДА В УМОВАХ КОМОРБІДНОСТІ
}

\section{Медикаментозна профрілактика хронічної серцевої недостатності після інфраркту міокарда в умовах коморбідності}

\section{М. В. Гребеник, Л. Ю. Бідованець}

Тернопільський національний медичний університет імені І. Я. Горбачевського МОЗ України

Резюме. Протягом останніх десятиліть етіологією хронічної серцевої недостатності $(\mathrm{XCH})$ є ішемічна хвороба серця (IXC), що згідно зі статистичними даними, домінує і займає перше місце у структурі смертності в Україні. Одним із найнебезпечніших клінічних проявів IXC є гострий інфраркт міокарда (IM), основним ускладненням якого $є$ розвиток серцевої недостатносmi $(\mathrm{CH})$. Незважаючи на розвиток сучасних технологій лікування IM, у тому числі з використанням інвазивних реперфузійних технологій, частина хворих із $\mathrm{CH}$ у віддаленому періоді неухильно зростає. Одним із провокуючих чинників розвитку і прогресування СН $\mathrm{C}$ наявність супутніх патологій у большості хворих на ІМ. Коморбідність з артеріальною гіпертензією та цукровим діабетом часто є пусковим фрактором розвитку IM [2]. Тому пошук найбільш придатних шляхів лікування IM, його ускладнень і мінімізація несприятливого післяінфрарктного ремоделювання серця і попередження розвитку СН є актуальною проблемою.

Мета дослідження - оптимізувати комплексну медикаментозну терапію у гострий період ІМ для попередження розвитку $\mathrm{CH}$ у хворих із коморбідною патологією.

Матеріали і методи. У дослідження включено 455 хворих на гострий IM з елевацією сегмента ST у віці $(62,7 \pm 1,07)$ року, серед них $342(75,16 \%)$ чоловіків і 113 (24,84\%) жінок, які істотно не різняться за віком, середній вік жінок склав $(61 \pm 0,83)$ року, чоловіків - $(63,05 \pm 0,98)$ року. Діагноз IM верифрікувати згідно із вітчизняним протоколом і ESC (2017). Використано клінічні, лабораторні та інструментальні методи дослідження. Внутрішньосерцеву гемодинаміку оцінювали використовуючи ехокардіографрію, післяінфрарктне ремоделювання проаналізовано протягом двох років. Усі пацієнти приймали статини, ß-блокатори та інгібітори ангіотензинперетворювального ферменту (ІАПФ). Хворих поділили на 3 групи. Перша група (n=232) (51\%) приймала раміприл в дозі 2,5-5,0 м2, друга група (n=171) (38 \%) - периндоприл 2,0-4,0 м2, третя група ( $n=52)(11 \%)$ - зофеноприл в стартовій
Medicamental prevention of congestive heart failure in patients after myocardial infarction in a state of comorbidities

M. V. Hrebenyk, L. Y. Bidovanets

I. Horbachevsky Ternopil National Medical University

e-mail: Ibidovanets@gmail.com

Summary. Over the past decades the main etiology of the congestive heart disease (CHD) is an ischemic heart disease (IHD). IHD, according to statistical data, dominates and ranks first in the structure of mortality in Ukraine. One of the most dangerous clinical manifestations of IHD is acute myocardial infarction (MI), the main complication of which is the development of heart failure. Despite the development of modern technologies for the treatment of myocardial infarction, including the use of invasive reperfusion technologies, the proportion of patients with heart failure in the longterm period of observation is steadily increasing. One of the provoking factors for the development and progression of heart failure is the presence of concomitant pathology in the majority of patients with MI. Comorbidity with arterial hypertension and diabetes mellitus is often a triggering factor in the development of MI [2]. That is why the search for the most suitable ways of treating myocardial infarction, its complications and minimizing pathological post-infarction cardiac remodeling, preventing the development of heart failure is an urgent problem.

The aim of the study - improvement of a complex drug therapy in the acute period of myocardial infarction to prevent the development of heart failure in patients with comorbid pathology.

Materials and Methods. Our study included 455 patients with an acute myocardial infarction with ST segment elevation at the age of $(62.7 \pm 1.07)$ years, among them $342(75.16 \%)$ men, and 113 (24.84 \%) women who approximately was the same age, the average age of women were $(61 \pm 0.83)$ years, men $-(63.05 \pm 0.98)$ years.

The diagnosis of MI was verified according to the local protocols [3] and ESC (2017). Clinical, laboratory and instrumental research methods were used. Intracardiac hemodynamics was assessed using echocardiography; post-infarction remodeling was analyzed in follow-up investigation during two years. All patients received statins, $\beta$-blockers, and angiotensin-converting enzyme (ACE) inhibitors. The patients were divided into 3 groups. Group $1(n=232)(51 \%)$ took ramipril at a dose of $2.5-5.0 \mathrm{mg}$, group $2(n=171)(38 \%)$ - perindopril 2.0-4.0 mg, group 
дозі 7,5 мг два рази на день. Призначення раміприлу $i$ зофеноприлу проводилося по черзі в міру надходження хворих у клініку, поки набір не набрав по 50 осіб у кожній групі (зофреноприл $(n=52))$. Периндоприл призначали пацієнтам старшого віку. Статистичну обробку проводили за допомогою пакета прикладних програм SPSS $® V .21 .0$ і редактора електронних таблиць Excel. Статистичний аналіз результатів проводили за допомогою програми SPSS v.21.0.

Результати. У цілому за супутніх патологією й індексом коморбідності Charlson групи обстеження не відрізнялися, що дозволило адекватно оцінити ефективніть дияреренційованого лікування. Застосування ІАПФ у післяінфрарктний період з точки зору патфрізіології має великий вплив на розвиток і фрормування післяінфрарктної СН. Для прогнозування розвитку СН протягом 3 місяців у динаміці досліджували рівні Nt-proBNP на тлі комбінованої терапії із використанням різних ІАПФ. Отримані результати підтвердили першість у використанні саме зофреноприлу пацієнтам, які перенесли IM на тлі коморбідності з метою попередити розвиток $\mathrm{CH}$.

Висновки. Згідно з отриманими результатами дослідження рівня динаміки Nt-proBNP, зроблено висновки про неоднаковий вплив різних препаратів ІАПФ на нейрогуморальні системи організму людини. А позитивні гемодинамічні й морфоорункціональні чинники дозволяють з упевненістю призначати цю фрармакологічну групу препаратів для лікування і поліпшення прогнозів у коморбідних хворих.

Ключові слова: інфраркт міокарда; коморбідність; вторинна профрілактика; зофеноприл.

\section{ВСТУП}

Упродовж останніх десятиліть провідними етіологічним чинником хронічної серцевої недостатності (CH) $є$ ішемічна хвороба серця (IXC). Остання, згідно із статистичними даними, домінує за поширеністю та посідає перше місце у структурі смертності в Україні [1]. Одним із самих небезпечних клінічних проявів IXC $€$ гострий інфраркт міокарда (IM), найбільш поширеним наслідком якого $€$ розвиток $\mathrm{CH}$. Незважаючи на розвиток сучасних технологій лікування IM, у тому числі з застосуванням інвазивних реперфузійних технологій, частка пацієнтів із $\mathrm{CH}$ у віддаленому післяінсрарктному періоді невпинно зростає.

Одним із провокуючих чинників розвитку і прогресування СН $є$ наявність супутньої патології у більшості хворих на IM. Коморбідність, зокрема з артеріальною гіпертензією (АГ) та цукровим діабетом (ЦД), не тільки впливає на розвиток ускладнень, $\mathrm{CH}$, але й часто $€$ безпосереднім найбільш частим фрактором ризику самого IM [2]. Тому пошук оптимальних шляхів лікування IM, його ускладнень та мінімізація несприятливого післяінсрарктного ремоделювання серця та попередження розвитку $\mathrm{CH}$ продовжує залишатись актуальною проблемою сьогодення. $3(n=52)(11 \%)$-zofenopril at a starting dose of $7.5 \mathrm{mg}$ twice a day. The prescription of ramipril and zofenopril was carried out in turn as patients entered the clinic. So far, the set was not amounted to 50 people in each group (zofenopril $n=52$ ). Perindopril was indicated for older patients. Statistical processing was performed using the SPSS $® V .21 .0$ software package and an Excel spreadsheet editor. Statistical analysis of the results was carried out using the SPSS V.21.0 program.

Results. In general, the study groups did not differ in concomitant pathology and the Charlson comorbidity index, which made it possible to adequately assess the effectiveness of differentiated treatment. The use of an ACE inhibitor in the postinfarction period from the point of view of pathophysiology has a great influence on the development and formation of postinfarction heart failure [4]. To predict the development of HF over 3 months after MI, the NtproBNP levels were studied in dynamics [5] using different ACE inhibitors in the treatment of patients with MI. The results obtained confirmed the benefits of the use of zofenopril in patients who suffered from $\mathrm{MI}$ in the background of comorbidity with the goal to prevent the development of HF.

Conclusions. According to the obtained results of the study of the level of Nt-proBNP dynamics, it was concluded that the effect of different ACE inhibitors on the neurohumoral systems of the human body is not the same. And positive hemodynamic and morphofunctional factors make it possible to confidently prescribe this pharmacological group of drugs for the treatment and improvement of prognosis in comorbid patients with MI.

Key words: myocardial infarction; comorbidity; secondary prevention; zofenopril.

Метою дослідження було оптимізувати комплексну медикаментозну терапію у гострий період IM для попередження розвитку СН у хворих із коморбідною патологією.

\section{МАТЕРІАЛИ I МЕТОДИ}

У дослідження включено 455 хворих на гострий IM з елевацією сегмента ST у віці $(62,7 \pm 1,07)$ року, з них 342 (75,16 \%) чоловіків, і 113 (24,84\%) жінок, які суттєво не відрізнялися за віком, середній вік жінок становив $(61 \pm 0,83)$ року, чоловіків $(63,05 \pm 0,98)$ року.

Діагноз IM верифрікували за чинними вітчизняними протоколами [3] та ESC (2017). Використано клінічні, лабораторні (загальноклінічні, біохімічні, у т. ч. імуноорерментні з визначенням натрійуретичних пептидів - Nt-proBNP) та інструментальні методи дослідження. Стан внутрішньосерцевої гемодинаміки оцінювали за допомогою ехокардіографії (ЕхоКС), післяінсрарктне ремоделювання серця проаналізовано в динаміці впродовж 2 років поспіль.

Усі пацієнти отримували статини, антитромбоцитарні засоби, Љ-блокатори та інгібітори ангіотензинперетворювального фрерменту (ІАПФ) упродовж
Вісник медичних і біологічних досліджень Bulletin of Medical and Biological Research 
часу спостереження. Залежно від призначеного ІАПФ хворих поділили на 3 групи. Перша група (n=232) (51\%) отримувала раміприл в дозі 2,5-5,0 мг, друга група (n=171) (38 \%) - периндоприл 2,04,0 мг, третя група (n=52) (11\%) - зофреноприл в початковій дозі 7,5 мг двічі на день із подальшим титруванням дози до 60 мг на добу. Призначення раміприлу і зофеноприлу проводилося почергово у міру надходження пацієнтів і до набору мінімальної статистичної групи більше 50 осіб (зофеноприл $\mathrm{n}=52)$. Периндоприл, як правило, призначали пацієнтам старшого віку.

Статистичну обробку проводили за допомого пакета прикладних програм SPSS®v.21.0 та редактора електронних таблиць Excel. Статистичний аналіз результатів проводили за допомогою програми SPSS v.21.0. Для порівняння середніх значень між групами використовували неспарений t-тест, а для оцінки динаміки показників у часі в межах однієї групи - спарений t-тест. Моделі динаміки показників у процесі довготривалого спостереження характеризували за коеоріцієнтом достовірності апроксимації $\left(\mathrm{R}^{2}\right)$. Для виявлення і встановлення рівня взаємозв'язку використано коесріцієнт кореляції Спірмена.

\section{РЕЗУЛЬТАТИ Й ОБГОВОРЕННЯ}

Супутню патологію у хворих на IM виявлено у 81,2 \% обстежених. Частка коморбідної патології у різних групах пацієнтів відображена в таблиці 1.

У цілому за поліморбідністю та індексом коморбідності Charlson групи обстежених не різнились, що дозволило надалі адекватно оцінювати еорективність дисреренційованої терапії. Найчастіше ІМ супроводжувала АГ - 73,0 \%. Інша судинна патологія в структурі коморбідності склала 22,3 \%. Серед цих пацієнтів найбільший відсоток становили особи $з$ перенесеним інсультом або транзиторними ішемічними атаками (8,0 \%), облітеруючим атеросклерозом нижніх кінцівок (3,4 \%). Судинні позакардіальні захворювання, зокрема мозкові інсульти достовірно частіше виявлялись у хворих на IM другої групи, що очевидно пов'язано з віковою різницею. Облітеруюче ураження судин нижніх кінцівок частіше діагностовано у пацієнтів третьої групи, де очевидно більший вплив на ураження судин мав цукровий діабет та ХОЗЛ, асоційоване 3 тютюнокурінням. Загалом, ЦД виявлено у 23,2 \% хворих на IM.

Патологія шлунково-кишкового тракту була досить вагомою в структурі коморбідності - 26,1 \%. В міру зниження частки супутня патологія розмістилась у наступному порядку: ревматичні хвороби $(6,3 \%)$, ХОЗЛ (16,83 \%), патологія нирок (6,0 \%), онкопатологія $(2,7 \%)$, захворювання щитоподібної залози (1,8 \%). Супутні ревматичні хвороби і патологія щитоподібної залози закономірно частіше виявлялись при ІМ у осіб жіночої статі (p=0,002).

Хворі з супутньою патологією були старші за віком $(p=0,03), \quad 3$ відносним збільшення частки осіб жіночої статі $(p=0,02)$ : співвідношення жінок до чоловіків становило 1:2 (в групі без супутньої патології - 1:5) та 3 перевагою пацієнтів 3 надмірною масою тіла ( $p=0,0001)$. Коморбідність по судинній патології тісно асоціювала 3 тютюнокурінням ( $r=0,201, p=0,001)$ та фрункціональним класом NYHA $(r=0,108, p=0,022)$. Поєднання IM 3 ревматичними захворюваннями, зокрема остеоартрозом, тісно корелювало з наявністю супутньої патології шлунково-кишкового тракту ( $r=0,192$, p=0,048), очевидно за рахунок вживання нестероїдних протизапальних середників. Останні, як відомо, мають вагомий вплив на серцево-судинну патологію, в тому числі - сприяють розвитку IM.

Для лікування IM на сьогодні застосовують загальноприйняті протоколи, в яких зазначено застосування (за відсутності протипоказань) тромболітиків, перкутанного коронарного втручання (ПКВ) або аортокоронарного шунтування, антитромбоцитарних засобів, статинів, ß-адреноблокаторів,

Таблиця 1. Супутня патологія в групах дослідження (\%)

\begin{tabular}{|c|c|c|c|c|}
\hline Патологія & $\begin{array}{c}\text { Перша група } \\
(n=232)\end{array}$ & $\begin{array}{c}\text { Друга група } \\
(\mathrm{n}=171)\end{array}$ & $\begin{array}{c}\text { Третя група } \\
(\mathrm{n}=52)\end{array}$ & $p$ \\
\hline Коморбідність (поліморбідність) & 79,7 & 81,3 & 82,7 & $p_{1-2-3}>0,05$ \\
\hline 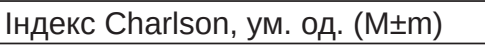 & $4,0 \pm 0,2$ & $5,0 \pm 0,4$ & $4,0 \pm 0,1$ & $p_{1-2-3}>0,05$ \\
\hline Артеріальна гіпертензія (АГ) & 76,3 & 75,5 & 67,3 & $p_{1-2-3}>0,05$ \\
\hline Перенесений інсульт /TIA & 6,0 & 12,3 & 5,8 & $p_{1-2}=0,026$ \\
\hline Облітеруючий атеросклероз & 2,2 & 2,3 & 7,7 & $p_{1-3}=0,036$ \\
\hline Цукровий діабет (ЦД) & 23,4 & 21,1 & 25,0 & $p_{1-2-3}>0,05$ \\
\hline Гастроентерологічна патологія & 26,3 & 25,1 & 26,9 & $p_{1-2-3}>0,05$ \\
\hline ХОЗЛ & 10,3 & 15,2 & 25,0 & $p_{1-3}=0,003$ \\
\hline Патологія нирок & 6,0 & 8,2 & 3,8 & $p_{1-2-3}>0,05$ \\
\hline $6,0 \% ; 2-7 \%$ & 6,0 & 7,0 & 5,8 & $p_{1-2-3}>0,05$ \\
\hline Онкопатологія & 3,4 & 2,9 & 1,9 & $p_{1-2-3}>0,05$ \\
\hline Патологія щитоподібної залози & 1,3 & 2,3 & 1,9 & $p_{1-2-3}>0,05$ \\
\hline
\end{tabular}


та обов'язково - ІАПФ або блокаторів рецепторів ангіотензину.

Однак коморбідна патологія негативно впливала на вибір фрармакоінвазивної технології лікування IM (r=-0,097, p=0,027). Вік пацієнтів теж мав стримуючий вплив на вибір лікування і застосування фрармакоінвазивної технології ( $r=-0,215, p=0,0001)$, призначення статинів ( $r=-0,135, p=0,002)$, аспірину $(r=-0,189, p=0,0001)$, тієнопіридинів ( $r=-0,087$, $p=0,048)$, ß-адреноблокаторів ( $r=-0,135, p=0,002)$.

Незважаючи на наявність супутньої патології травної системи, зокрема виразкової хвороби (перша група - 11,2 \%; друга - 9,9 \%; третя - 9,6 \%), більшості пацієнтам призначали аспірин у гострий період IM (r=-0,078, p=0,075).

Супутня онкопатологія мала вплив на обмеження у призначенні антитромбоцитарних препаратів, зокрема аспірину ((r=-0,238, $p=0,0001)$ і клопідогрелю $(r=-0,140, p=0,002)$ та статинів $(r=-0,126, p=0,005)$.

Застосування ІАПФ у післяінсрарктному періоді, з точки зору патофрізіології, має величезний вагомий вплив на фрормування та розвиток післяінорарктного серця та СН [4]. Для прогнозування розвитку СН упродовж 3 місяців у динаміці визначено рівні Nt-proBNP [5] на тлі комбінованої терапії із застосуванням різних ІАПФ. Отримані результати (табл. 2) визначили префреренції застосування саме зофеноприлу з метою попередження розвитку хронічної СН у післяінфрарктних хворих в умовах коморбідної патології. Оскільки одним із фракторів формування післяінорарктної СН $€$ ремоделювання міокарда, простежено його прояви упродовж 24 місяців (у перший рік - через 3, 6,12 міс. після IM) на тлі диореренційованої терапії (табл. 2).

Післяінфарктне ремоделювання було найбільш оптимальним в третій групі й характеризувалось збереженням передньо-заднього розміру та об'єму лівого передсердя в групі, зменшенням дилатації камер серця із збереженням їх нормальної геометрії, масометричних показників та відновленням скоротливості лівого шлуночка до 2 року спостереження

Таблиця 2. Динаміка Nt-proBNP і морфофункціональних характеристик міокарда за даними ехокардіоскопії у групах

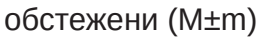

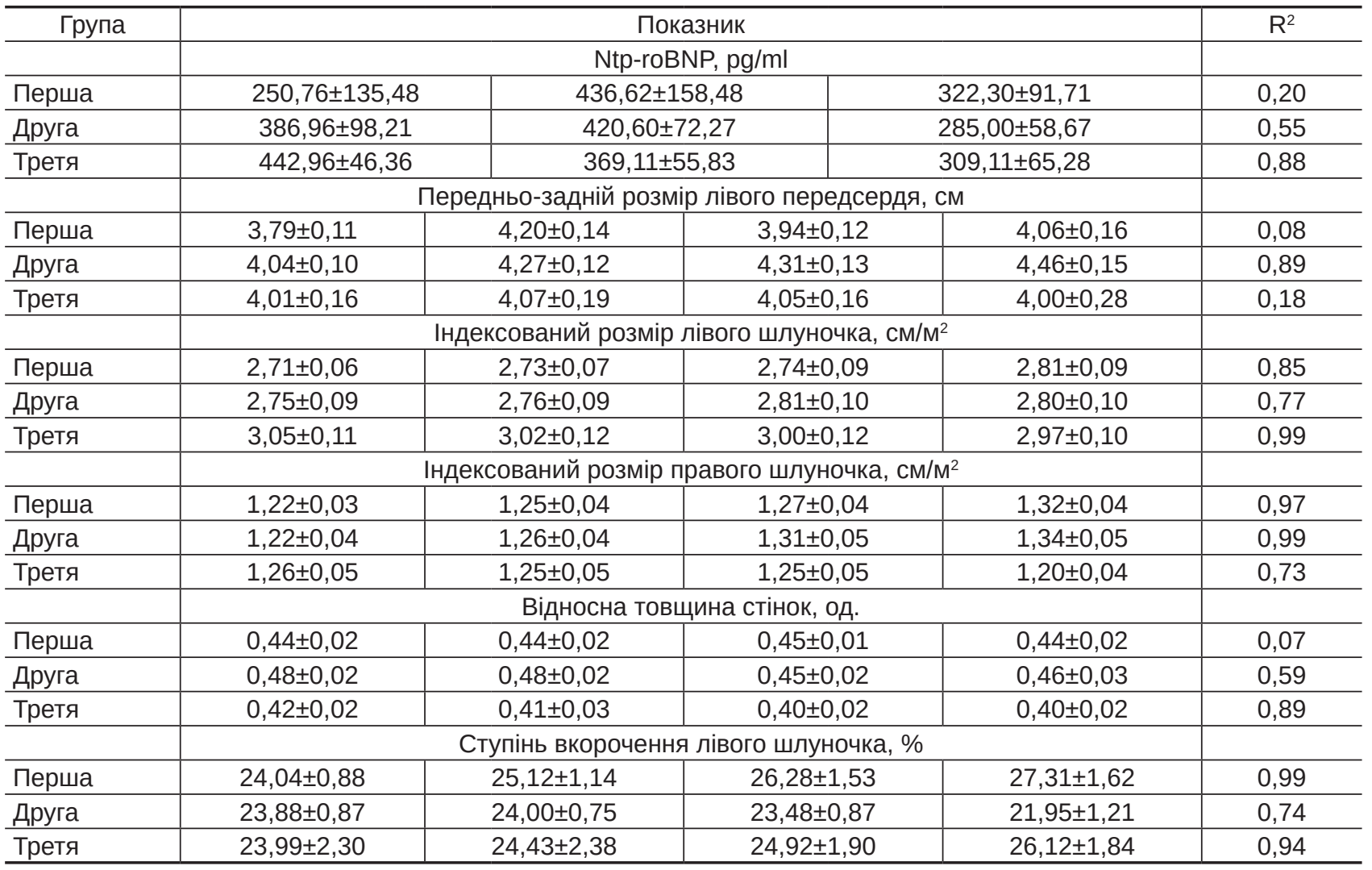

Примітка. $\mathrm{R}^{2-}$ коефріцієнт достовірності апроксимації.

\section{ВИСНОВКИ}

За отриманими результатами, неоднаковий вплив різних ІАПФ на нейрогуморальні механізми патології (у нашому випадку - за резуль- татами динаміки Nt-proBNP), гемодинамічні та морфоорункціональні чинники (за даними ульстрасонографрічного дослідження) післяінфрарктного ремоделювання серця є підставою для 
диореренційованого призначення цієї фрармакологічної групи препаратів для оптимізації лікування

\section{СПИСОК ЛІТЕРАТУРИ}

1. Державна служба статистики України, 2019. Населення України за 2018 рік. Демографрічний щорічник Коефіцієнти смертності за основними класами причин смерті, статтю померлих // http://www.ukrstat.gov.ua/druk/ publicat/kat_u/2019/zb/12/zb_ukr_2018.pdf

2. George A. Impared glucose tolerance or newly diagnosed diabetes mellitus diagnosed during admission adversely affects prognosis after myocardial infarction: an observational study / A. George, R. T. Bhatia, G. L. Buchanan [et al.] // Plos One. - 2015. - Vol. 10, No. 11. - P. 1-11.

3. Серцево-судинні захворювання. Класифрікація, стандарти діагностики та лікування / Всеукр. асоц. кар-

\section{REFERENCES}

1. Coefficient of mortality according to the main causes of death, sex of the died people. State department of statistics in Ukraine, 2019. Inhabitants of Ukraine in 2018. Lemographycal situation in Ukraine every year. Available from: http://www.ukrstat.gov.ua/druk/publicat/kat u/2019/ zb/12/zb_ukr_2018.pdf. Ukrainian.

2. George A, Raghav T, Bhatia T, Gill L., Buhanan. Impared glucose tolerance or newly diagnosed diabetes mellitus diagnosed during admission adversely affects prognosis after myocardial infarction: an observational study. Plos One. 2015;10(11): 1-11.

3. Kovalenko V.M. Cardio-vascular diseases. Classification, standards in diagnostic and treatment process. $3^{\text {rd }}$ і покращення найближчого і віддаленого прогнозу в коморбідних пацієнтів.

діологів ; за ред. В. М. Коваленка [та ін.]. - 3-тє вид., переробл. і допов. - К. : Моріон, 2018. - 223 с.

4. Патосрізіологічні механізми розвитку і прогресування міокардіальної диссункції у пацієнтів із гострим інсрарктом міокарда / В. П. Іванов, О. В. Щербак, О. Ф. Білонько, В. П. Щербак // Укр. мед.часопис. - 2015. - T. 4, № 108. - C. 26-30.

5. Which heart failure patients profit from natriuretic peptide guided therapy? A meta-analysis from individual patient data of randomized trials / Hans-Peter Brunner-La Rocca, Luc Eurlings, A. Mark Richards [et al.] // European Journal of Heart Failure. - 2015. - Vol.17, Issue12. P. 1252-1261.

Eddition. [Серцево-судинні захворювання. Класифрікація, стандарти діагностики та лікування] Kyiv: Morion; 2018. Ukrainian.

4. Ivanow BP, Shcherbak OF, Bilonko VP. [Pathophysiological mechanisms of development and progression of myocardial dysfunction in patients with myocardial infarction]. Ukr med chasopys. 2015;4(108). Ukrainian.

5. Hans-Peter Brunner-La Rocca, Luc Eurlings, A. Mark Richards. Which heart failure patients profit from natriuretic peptide guided therapy? A meta-analysis from individual patient data of randomized trials. European Journal of Heart Failure. 2015;17(12): 1252-61. 